\title{
EFFECT OF DIET ON MALE REPRODUCTIVE TRACT OF Podisus nigrispinus (DALLAS) (HETEROPTERA: PENTATOMIDAE)
}

\author{
LEMOS, W. P., ${ }^{1,4}$ SERRÃO, J. E., RAMALHO, F. S., ${ }^{3}$ \\ COLA ZANUNCIO, J. C. ${ }^{1}$ and LACERDA, M. C. ${ }^{1}$ \\ ${ }^{1}$ Departamento de Biologia Animal, Universidade Federal de Viçosa, \\ CEP 36571-000, Viçosa, Minas Gerais, Brazil \\ ${ }^{2}$ Departamento de Biologia Geral, Universidade Federal de Viçosa, \\ CEP 36571-000, Viçosa, Minas Gerais, Brazil \\ ${ }^{3}$ Unidade de Controle Biológico (UCB)/Embrapa Algodão, C.P. 174, \\ CEP 58107-720, Campina Grande, Paraíba, Brazil \\ ${ }^{4}$ Laboratório de Entomologia, Embrapa Amazônia Oriental, C.P. 048, CEP 66095-100, Belém, Pará, Brazil \\ Correspondence to: José Eduardo Serrão, Departamento de Biologia Geral, Universidade Federal de Viçosa, \\ CEP 36571-000, Viçosa, Minas Gerais, Brazil, e-mail: jeserrao@ufv.br \\ Received May 13, 2003 - Accepted September 9, 2003 - Distributed February 28, 2005
}

(With 2 figures)

\begin{abstract}
The morphology and histology of the reproductive tract of males of the predator Podisus nigrispinus (Dallas) fed on different diets were studied. P. nigrispinus was fed on diets of: larvae of Alabama argillacea (Hübner), Tenebrio molitor L., Musca domestica L., and an artificial diet. The male reproductive tract, independent of diet, showed testes with intense red coloration in a compact, circular, or slightly oval structure. The vasa deferentia were similar in color to the testes and formed long filaments, which joined with the yellow-cream colored ejaculatory duct. The morphological characteristics of the male reproductive tract were similar under all diets, except for the artificial one. The histological studies demonstrated that independent of the diet the testes of $P$. nigrispinus were composed of four to six follicles. The testes with six follicles generally had four developed and two atrophied follicles. The morphological and histological differences of the testes of $P$. nigrispinus when fed with different prey are presented and discussed.
\end{abstract}

Key words: Asopinae, biological control, morphology, testis, predator.

\section{RESUMO}

\section{Efeito da dieta no órgão reprodutivo de machos de Podisus nigrispinus (Dallas) (Heteroptera: Pentatomidae)}

Estudou-se a morfologia e a histologia do órgão reprodutivo de machos do predador Podisus nigrispinus (Dallas), alimentados com diferentes dietas (lagartas de Alabama argillacea (Hübner), larvas de Tenebrio molitor L., larvas de Musca domestica L. e dieta artificial). O órgão reprodutivo dos machos, independentemente da dieta fornecida, apresentou testículos com coloração vermelha intensa, compactos e de aspecto circular ou ligeiramente ovóide. Os canais deferentes apresentaram coloração semelhante a dos testículos e forma de filamentos longos, os quais se conectam a um duto ejaculatório de coloração creme-amarelada. As características morfológicas do órgão reprodutivo dos machos foram similares em todas as dietas, exceto quando alimentados com dieta artificial. Os estudos histológicos demonstraram que, independentemente da dieta, os testículos de P. nigrispinus são compostos por quatro a seis folículos. Os testículos com seis folículos geralmente têm quatro folículos desenvolvidos e dois atrofiados. Este trabalho apresenta e discute as diferenças morfológicas e histológicas dos testículos de P. nigrispinus alimentados com as diferentes dietas.

Palavras-chave: Asopinae, controle biológico, morfologia, testículo, predador. 


\section{INTRODUCTION}

Due to the growing pressure of society and researchers for an agriculture that is economically viable and ecologically healthy, the importance of using natural enemies in pest control has been increasing, especially due to environmental problems and social and ecological impacts caused by chemical products. Therefore, natural enemies are important in integrated pest management (IPM) programs aiming at population balance of insect pests (Molina-Rugama et al., 1997).

Podisus nigrispinus (Dallas) (Heteroptera: Pentatomidae) is one of the most common Asopinae species in the Neotropical region (De Clercq, 2000) as well as an important agent of biological control in field-crop systems (Michel, 1994; Zanuncio et al., 1994; Santos et al., 1995, 1996; Moreira et al., 1998; Lemos et al., 2001, 2003) in several countries of South and Central America (Thomas, 1992). P. nigrispinus is a polyphagous predator preying on cotton leafworm [Alabama argillacea (Hübner)] larvae (Medeiros et al., 2000; Lemos et al., 2003) in cotton ecosystems in Brazil (Medeiros et al., 1998, 2000) and Paraguay (Michel, 1994).

In spite of the importance of heteropteran predators, studies related with the biology, ecology, and systematics of these insects are recent in Brazil (Grazia \& Hildebrand, 1987), which may suggest that the potential of these biological control agents is greater than currently recognized.

The male reproductive tract of heteropteran insects typically consists of a pair of testes and a pair of vasa deferentia that end in a medium ejaculatory duct (Davey, 1985; Happ, 1992; Nijhout, 1994; Chapman, 1998). Most insects present a number of accessory glands, which open into the vasa deferentia or the ejaculatory duct (Happ, 1992; Chapman, 1998).

In general, each testis is composed of a number of testis tubes or follicles (Nijhout, 1994; Chapman, 1998) ranging from one in some coleopterans to over 100 in some Acrididae grasshoppers (Chapman, 1998). Each follicle has its own germarium, analogous to the ovarioles of females, except that the testicular follicles are generally encased in a common sheath, making the testis a fairly compact body (Nijhout, 1994).

Despite the importance of Pentatomidae as biological control agents, few reports exist on the internal morphology of the reproductive tract of these organisms, especially with reference to male reproductive system.

Food ingested during the immature stage affects adult size, which may influence the fecundity and/or the reproductive strategy of insects (Sowing et al., 1997). Thus, availability of suitable diets is highly desirable for mass rearing entomophagous insects, including heteropteran predators (Waage et al., 1985).

Due to lack of anatomical and histological studies of the reproductive tract of male stinkbug predators, the objective of this research was to study the effect of different prey (larvae of $A$. argillacea, Tenebrio molitor, and Musca domestica as well as an artificial die) on the anatomy and histology of the male reproductive tract of the predator $P$. nigrispinus.

\section{MATERIALS AND METHODS}

The research was carried out at the Unidade de Controle Biológico (UCB)/Embrapa Algodão, Campina Grande, Paraíba State, Brazil and the morphological studies of the reproductive tract of the predator were done at the Laboratório de Biologia Molecular e Celular, Departamento de Biologia Geral, Universidade Federal de Viçosa, Viçosa, Minas Gerais State, Brazil.

Specimens of the predator $P$. nigrispinus and of the prey A. argillacea, T. molitor, and $M$. domestica were obtained from colonies maintained at the UCB/Embrapa Algodão, according to procedures of Azevedo (1996) and Medeiros (1997). The artificial diet for rearing P. nigrispinus was prepared as described by Saavedra et al. (1995) and consisted of cattle liver ( $60 \mathrm{~g})$, ground beef $(60 \mathrm{~g}), 5 \%$ sucrose solution $(18 \mathrm{ml})$, Wesson salts $(0.6 \mathrm{~g})$, brewer's yeast $(3.0 \mathrm{~g})$, chicken egg yolk $(12.0 \mathrm{~g})$, honey $(7.2 \mathrm{~g})$, ascorbic acid $(0.3 \mathrm{~g})$, nipagin $(0.3 \mathrm{~g})$, and tetracycline $(0.03 \mathrm{~g})$.

Individuals of $P$. nigrispinus were maintained during nymph and adult stages at $25 \pm 2^{\circ} \mathrm{C}$, relative humidity of $60 \pm 10 \%$, and L:D 14:10 photoperiod on all of the five diets described, in accordance with the following treatments: $\left(\mathrm{D}_{1}\right)$ third instar larvae of A. argillacea; $\left(\mathrm{D}_{2}\right)$ fifth instar larvae of $A$. argillacea; $\left(\mathrm{D}_{3}\right)$ artificial diet; $\left(\mathrm{D}_{4}\right)$ third instar larvae of T. molitor; and $\left(\mathrm{D}_{5}\right)$ third instar larvae of $M$. domestica. 
Newly emerged $P$. nigrispinus adults were sexed based on the external appearance of genitalia and on body size. After mating, males were dissected to remove their reproductive tract, which were then transferred to $4 \%$ paraformaldehyde at phosphate buffer $0.1 \mathrm{M} \mathrm{pH} \mathrm{7.4.}$

Anatomical descriptions and morphological characteristics of the reproductive tract of $P$. nigrispinus were analyzed in ten individuals on each tested diet.

The male reproductive tracts were subsequently dehydrated in a series of increasing concentrations of ethyl alcohol embedded in historesin (Leica). Sections of $4 \mu \mathrm{m}$ thickness were stained with hematoxilin and eosin.

\section{RESULTS}

Analysis under stereomicroscope revealed that the male reproductive tract of $P$. nigrispinus lies below the gut, is surrounded by fat body, and is characterized by a pair of testes, a pair of vasa deferentia, and an ejaculatory duct (Fig. 1).

Testes were located in the initial region of the abdomen and had an intense red color and a compact structure with a circular (Fig. 1) or slightly oval (Fig. 2) shape. Follicles within the testes were only differentiated through histological studies. The vasa deferentia, also showing an intense red color, had long filaments reaching the distal region of the abdomen and joined to the yellow creamcolored ejaculatory duct. The ejaculatory duct is linked to the aedeagus (mating organ) in the terminal part of the reproductive tract (Fig. 1).

The histological studies of the internal gonad of $P$. nigrispinus males demonstrated that this species independently of the diet presents each testis composed of either four or six follicles. This was found for all food types consumed by P. nigrispinus during its nymphal stage. The testes of $P$. nigrispinus that have six follicles generally have four that are well developed (wider) in the central region and two that are atrophied on the periphery (Figs. 3, 4).

Each follicle of $P$. nigrispinus has a germarium in the apical region; testicular follicles are lined by a layer of cells (peritoneal sheath) and a non-cellular layer (tunica propria) (Figs. 3, 4).

A membrane forms a cyst surrounding groups of spermatocytes within each follicle. All sper- matocytes within the cysts in P. nigrispinus developed synchronously along the follicles in the direction of the vasa deferentia region (Fig. 5). Thus, it is possible to find spermatocytes in different developmental stages in the follicles. When they approach the vasa deferentia, the spermatids are differentiated and inside the vasa deferentia (Fig. 6) produce the spermatozoa, which are liberated from each cyst grouped together in bundles (Fig. 7).

In the follicle region near the vasa deferentia and irrespective of prey type (diet) that the predator ingested, a great amount of spermatozoa were found, which may indicate that in this region the spermatogenesis process had already been completed.

A relatively narrow and short vas efferens connects to the vas deferens in each follicle, which is a long tube with a flattened epithelium, a basal lamina, and an outer muscle layer (Fig. 7).

The diet supplied to $P$. nigrispinus did not affect the morphological and histological features of the testes of this predator, which presented the same pattern previously described for males fed on different diets. The only difference was that the testes of individuals fed on the artificial diet showed a high degree of cell death, characterized by the appearance of picnotic cell nuclei (Fig. 8). Only one testis of individuals fed on T. molitor also showed evidence of cell death, with no additional case seen in insects fed with on the other diets.

\section{DISCUSSION}

The intense red color of the testes of $P$. nigrispinus seems to be a peculiar morphological characteristic of this group of stinkbug predators. However, studies on the nature of testicular tissues are rare, showing the necessity of further investigations to discover the origin of this color.

The food type consumed by the predator $P$. nigrispinus during its nymphal stage did not change the number of follicles/testis, suggesting that the number of follicles is species-specific, as are the number of ovarioles per ovary in Heteroptera (Büning, 1994).

We found that within each follicle a cellular membrane that forms a cyst surrounds groups of spermatocytes. In heteropterans, according to Chapman (1998), large cells with irregular nuclei, called trophocytes, are scattered among the cysts. 
The gametogenesis process in males has been receiving less attention than the similar event in females because the latter is generally considered more important in reproductive strategies. For this reason there is more research available on chemical and biological control using these insects (Dumser, 1980).

According to Loher \& Edson (1973), the factors that stimulate oogenesis and oviposition in the cricket Teleogryllus commodus Walker derive from testes of this insect, because fecundity of females mated with males that had accessory glands excised was similar to those mated with normal males, while fecundity was lower when females were mated with castrated males. Thus, as males of $P$. nigrispinus fed on the artificial diet presented patterns of cell death in the testes, it may be expected that these individuals also present reduced viable spermatozoa production. This may be one of the factors responsible for lower egg production in females of this stinkbug predator fed, and copulated with males fed, on an artificial diet (Lemos, 2001).

Increasing cell death can be due to nutritional deficiencies of an artificial diet, because apoptosis enhancing has been reported in gut, ovary, and nerve cell culture of mammals subjected to starvation, fasting, or dietary restriction (Chappell et al., 2003; Mukherjee et al., 2002; Simon \& Karim, 2002). Nutritional deficiency in the artificial diet supplied to P. nigrispinus may signify absence of some amino acid that perhaps cannot be obtained from digesting bovine proteins in the diet. Simon \& Karim (2002) have pointed out that asparagine and glutamine are two major amino acids that play a role in the suppression of apoptosis in ovary cell culture in Chinese hamsters.

Spermatozoa production and transfer of seminal mass to the female require significant investments of biochemical resources and temporal coordination of development in several organs, especially in the gonads (Happ, 1992). Davey (1958) has pointed out that proteins and carbohydrates are components present in the secretions of accessory glands of hemipterans. However, only a few protein contents in seminal secretions of insects have been characterized and further studies are required on their significance.

It was verified that different prey did not influence development of the reproductive tract of $P$. nigrispinus males. However, there is some evidence of cell death in the testes of individuals of this predator fed on an artificial diet.
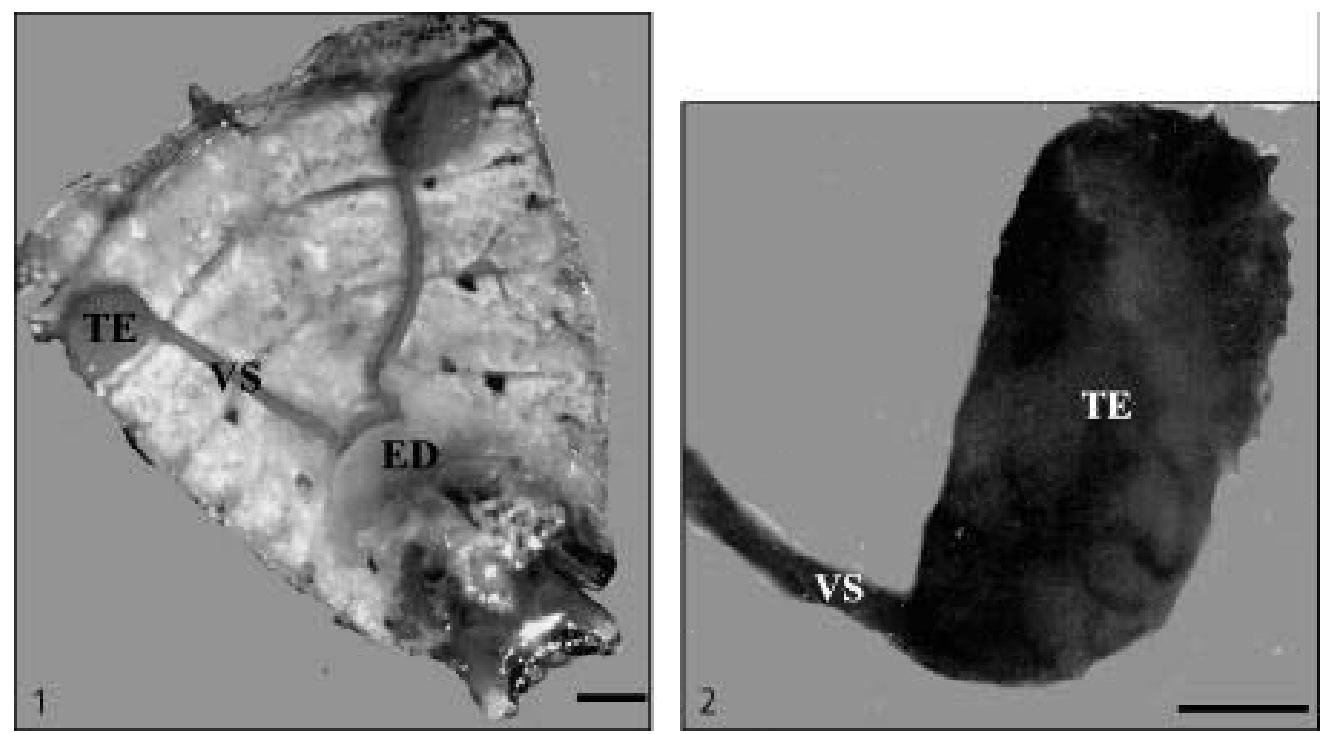

Figs. 1-2 - Male reproductive tract of P. nigrispinus. (1) General view. (2) Details of elongated testis. TE $=$ testis, ED = ejaculatory duct, VS $=$ vas deferens. Bars $=100 \mu \mathrm{m}$. 

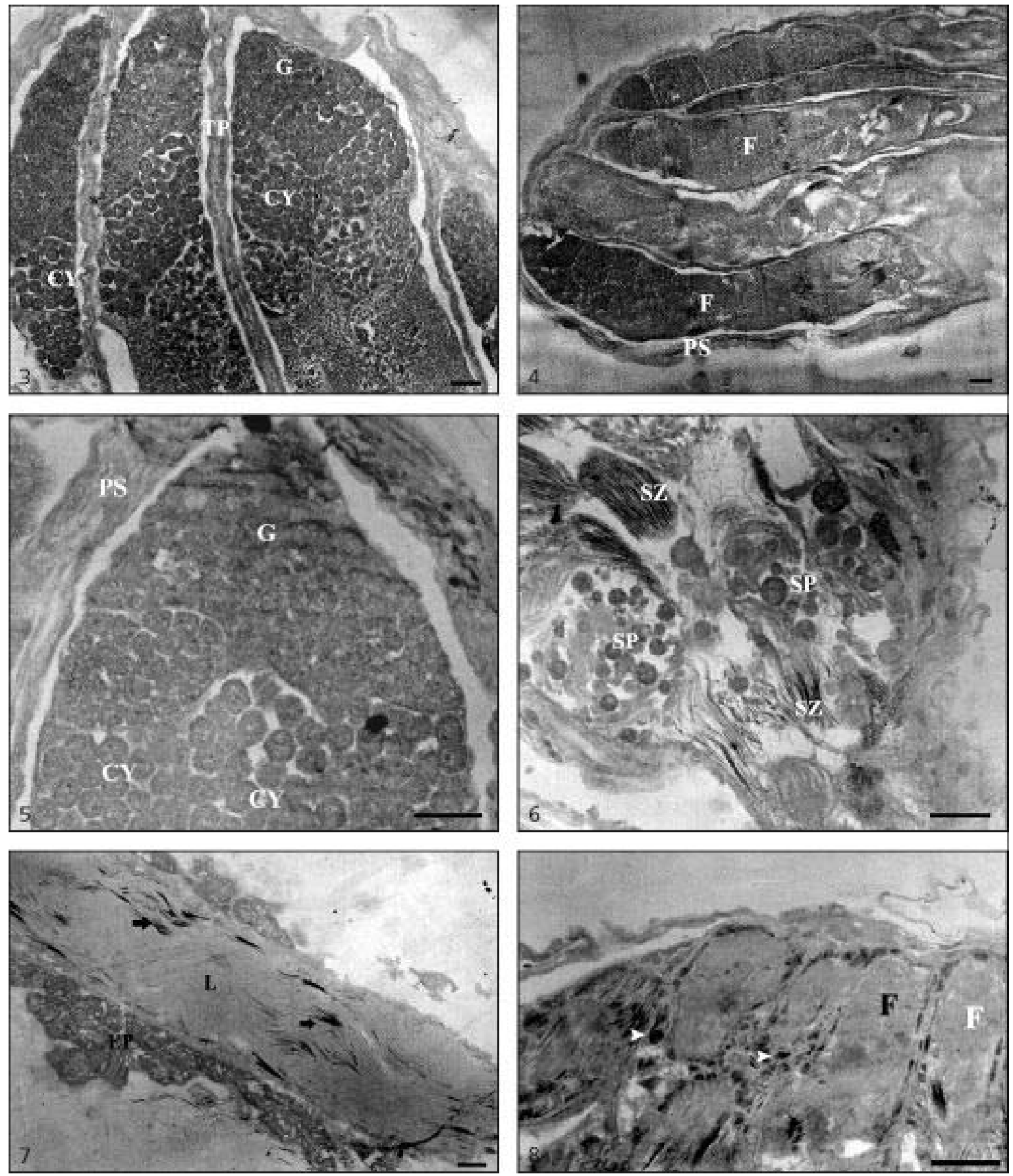

Figs. 3-8 - Longitudinal sections of testes of P. nigrispinus. $(3,4)$ - Different numbers of follicles (F). (5) - Germarium region $(\mathrm{G})$ showing the beginning of the differentiation of the spermatocytes forming cysts (CY). (6) - Region near the vasa deferentia showing the presence of spermatocytes (SP) at different developmental stages and differentiated spermatozoa (SZ). (7) - General view of lumen (L) of the vas deferens with large amount of spermatozoa bundles (arrows). (8) - General view of the testis of $P$. nigrispinus fed on artificial diet showing high degree of cell death (arrowheads). $\mathrm{TP}=$ tunica propria; $\mathrm{PS}=$ peritoneal sheath; $\mathrm{EP}=$ epithelium. Bars $=50 \mu \mathrm{m}$.

Acknowledgements - We thank Dr. R. Charudattan (Department of Entomology/University of Florida) for his helpful comments on earlier drafts of this manuscript. We also express our appreciation to the personnel at the Biological Control Unit/Embrapa Algodão, specially those responsible for rearing predators and prey used in this research, and to the General Biology and Animal Biology departments of the Federal University of Viçosa. Research was supported by funds from CAPES, FAPEMIG, and CNPq. 


\section{REFERENCES}

AZEVEDO, F. R., 1996, Efeitos da temperatura e defesa da presa no consumo e utilização de larvas de Tenebrio molitor Linné por ninfas do predador Supputius cincticeps (Stäl, 1860) (Hemiptera: Pentatomidae). Dissertação de Mestrado, UFRPE, Recife, 101p.

BÜNING, J., 1994, The ovary of ectognatha, the Insecta s. str. pp. 31-324. In: J. Büning (ed.), The insect ovary ultrastructure, previtellogenic growth and evolution. Chapman \& Hall, London, UK, 400p.

CHAPMAN, R. F., 1998, Reproductive system: male. pp. 268294. In: R. F. Chapman (ed.), The insects: structure and function. Cambridge University, Cambridge, 770p.

CHAPPELL, V. L., THOMPSON, M. D., JESCHKE, M. G., CHUNG, D. H., THOMPSON, J. C. \& WOLF, S. E., 2003, Effect of incremental starvation on gut mucosa. Digest. Dis. Sci., 48: 765-769.

DAVEY, K. G., 1958, The migration of spermatozoa in the female of Rhodinus prolixus Stal. J. Exp. Biol., 35: 694-701.

DAVEY, K. G., 1985, The male reproductive tract. pp. 1-14. In: G. A. Kerkut \& L. I. Gilbert (eds.), Comprehensive insect physiology, biochemistry and pharmacology. Pergamon Press, Oxford.

DE CLERCQ, P., 2000, Predaceous stinkbugs (Pentatomidae:Asopinae). pp. 737-789. In: C. W. Schaefer \& A. R. Panizzi (eds.), Heteroptera of economic importance. Cambridge University, Cambridge, 828p.

DUMSER, J. B., 1980, The regulation of spermatogenesis in insects. Annu. Rev. Entomol., 25: 341-369.

GRAZIA, J. \& HILDEBRAND, R., 1987, Hemípteros predadores de insetos. pp. 21-37. In: CPACT/EMBRAPA (ed.), Encontro sul-brasileiro de controle de pragas. AEAPF-CPACT/ EMBRAPA, Passo Fundo.

HAPP, G. M., 1992, Maturation of the male reproductive system and its endocrine regulation. Annu. Rev. Entomol., 37: 303320 .

LEMOS, W. P., 2001, Efeito de diferentes presas no desenvolvimento das estruturas reprodutivas e na reprodução do predador Podisus nigrispinus (Heteroptera: Pentatomidae). Dissertação de Mestrado, UFV, Viçosa, 106p.

LEMOS, W. P., MEDEIROS, R. S., RAMALHO, F. S. \& ZANUNCIO, J. C., 2001, Effects of plant feeding on the development, survival, and reproduction of Podisus nigrispinus (Dallas) (Heteroptera:Pentatomidae). Intern. J. Pest Manage., 27: 89-93.

LEMOS, W. P., RAMALHO, F. S., SERRÃO, J. E. \& ZANUNCIO, J. C., 2003, Effects of diet on development of Podisus nigrispinus (Dallas) (Heteroptera: Pentatomidae), a predator of the cotton leafworm. J. Appl. Entomol., 128: 12-25.

LOHER, W. \& EDSON, K., 1973, The effect of mating on egg production and release in the cricket. Teleogryllus commodus. Entomol. Exp. Appl., 16: 483-490.

MEDEIROS, R. S., 1997, Efeitos da temperatura na biologia de Podisus nigrispinus (Dallas, 1851) (Hemiptera: Pentatomidae), predador do curuquerê-do-algodoeiro. Monografia, UFPB, Areia, 90p.
MEDEIROS, R. S., LEMOS, W. P. \& RAMALHO, F. S., 1998, Efeitos da temperatura no desenvolvimento de Podisus nigrispinus (Dallas) (Heteroptera, Pentatomidae), predador do curuquerê-do-algodoeiro (Lepidoptera, Noctuidae). Revta Bras. Ent., 42: 121-130.

MEDEIROS, R. S., RAMALHO, F. S., LEMOS, W. P. \& ZANUNCIO, J. C., 2000, Age-dependent fecundity and lifefertility tables for Podisus nigrispinus (Dallas) (Het., Pentatomidae). J. Appl. Entomol., 124: 319-324.

MICHEL, B., 1994, Entomofauna de los algodonales paraguayos: Hemiptera: Heteroptera. Ministério de Agricultura y Ganadería, Asunción, 132p.

MOLINA-RUGAMA, A. J., ZANUNCIO, J. C., TORRES, J. B. \& ZANUNCIO, T. V., 1997, Longevidad y fecundidad de Podisus nigrispinus (Heteroptera: Pentatomidae) alimentado con Musca domestica (Diptera: Muscidae) y frijol. Revta Biol. Trop., 45: 1125-1130.

MOREIRA, L. A., ZANUNCIO, J. C. \& MOLINA-RUGAMA, A. J., 1998, Dados biológicos de Podisus nigrispinus (Dallas) alimentado com a lagarta do maracujazeiro Dione juno juno (Cramer). An. Soc. Entomol. Brasil, 27: 645-647.

MUKHERJEE, P., EL-ABBADI, M. M., KASPERZYK, J. L., RANES, M. K. \& SEYFRIED, T. N., 2002, Dietary restriction reduces angiogenesis and growth in an orthotopic mouse brain tumour model. Brit. J. Cancer, 86: 1615-1621.

NIJHOUT, H. F., 1994, Reproduction. pp. 142-159. In: H. F. Nijhout (ed.), Insect Hormone. Princeton University, Princeton.

SAAVEDRA, J. L. D., ZANUNCIO, J. C., SEDIYAMA, C. S. \& ZANUNCIO, T. V., 1995, Fecundidad y fertilidad del predador Podisus nigrispinus (Dallas) (Heteroptera: Pentatomidae) en cuatro dietas artificiales. Turrialba, 45: 70-75.

SANTOS, T. M., SILVA, E. N. \& RAMALHO, F. S., 1995, Desenvolvimento ninfal de Podisus connexivus Bergroth (Hemiptera: Pentatomidae) alimentado com curuquerê-doalgodoeiro. Pesq. Agrop. Bras., 30: 163-167.

SANTOS, T. M., SILVA, E. N. \& RAMALHO, F. S., 1996, Consumo alimentar e desenvolvimento de Podisus nigrispinus (Dallas) sobre Alabama argillacea (Hüebner) em condições de laboratório. Pesq. Agrop. Bras., 31: 699-707.

SIMON, L. \& KARIM, M. N., 2002, Control of starvationinduced apoptosis in Chinese ovary cell cultures. Biotechnol Bioeng., 78: 645-657.

SOWING, P., HIMMELSBACH, R. \& HIMMELSBACH, W., 1997, Predator-prey relationship between insect larvae: growth of Sphaeridium larvae (Coleoptera: Hydrophilidae) under time constraints through predation on Musca autumnalis maggots (Diptera: Muscidae). Can. J. Zool., 75: 2069-2076.

THOMAS, D. B., 1992, Taxonomic synopsis of the Asopinae Pentatomidae (Heteroptera) of the Western hemisphere. Entomological Society of America, Lanham, 156p.

WAAGE, J. K., CARL, K. P., MILES, N. J. \& GREATHEAD, D. J., 1985, Rearing entomophagous insects. pp. 45-66. In: P. Singh \& R. F. Moore (eds.), Handbook of insect rearing. Elsecier, Amsterdam.

ZANUNCIO, J. C., ALVES, J. B., ZANUNCIO, T. V. \& GARCIA, J. F., 1994, Hemipterous predators of eucalypt desfoliator caterpillars. Forest Ecol. Manage., 65: 65-73. 